\title{
ANALISIS RASIO KEUANGAN TERHADAP KINERJA KEUANGAN PT. ANGKASA PURA II (PERSERO) PERIODE 2017 - 2019
}

\author{
Arini Dewi Chintyana ${ }^{1}$, Cyntiana Kosasih ${ }^{2}$, Dea Novita ${ }^{3}$, Dedeh Ropikoh ${ }^{4}$, \\ Deni Rizki Rifaldi ${ }^{5}$, Dewi Hanitri ${ }^{6}$, Dina Anggi Lestari ${ }^{7}$, Lilis Sulastri ${ }^{8}$ \\ 1,2,3,4,5,6,7,8 Universitas Islam Negeri Sunan Gunung Djati Bandung \\ Email :Cyntianakosasih123@gmail.com
}

\begin{abstract}
Abstrak
Penelitian ini berjudul Analisis Rasio Keuangan Terhadap Kinerja Keuangan PT. Angkasa Pura II (Persero) Periode 2017-2019. Tujuan dari penelitian ini adalah untuk melihat perbandingan kinerja keuangan perusahaan yang diukur melalui analisis rasio keuangan, yang terdiri dari : Rasio Likuiditas (Current Ratio, Quick Ratio, Cash Ratio), rasio solvabilitas (Debt to Asset Ratio, Debt to Equity Ratio, Long Term Debt to Equity Ratio, Time Interest Earned Ratio), rasio aktivitas (Total Asset Turn Over Working Capital Turn Over, Fixed Asset Turn Over) dan rasio profitabilitas (Net Profit Margin, Operating Profit Margin, Return on Asset, Return on Equity, Earning Per Share). Yang menjadi objek penelitian adalah PT. Angkasa Pura II (Persero). Jenis penelitian yang dilakukan adalah penelitian deskriptif. Fokus penelitian adalah laporan keuangan perusahaan yang terdiri dari laporan neraca dan Laporan laba rugi periode tahun 2017-2019. Sumber data yang digunakan adalah data sekunder yang diperoleh dari website www.angkasapura2.co.id . Analisis data yang digunakan dalam penelitian ini adalah analisis deskriptif dengan menggunakan analisis rasio keuangan. Hasil penelitian ini menunjukan kinerja keuangan PT. Angkasa Pura II (Persero) periode 2017-2019 yang terdiri dari rasio likuiditas, solvabilitas, aktivitas dan profitabilitas.
\end{abstract}

Kata kunci : Rasio Likuiditas, Rasio Solvabilitas, Rasio Aktivitas, Rasio profitabilitas dan Kinerja Keuangan

\begin{abstract}
The title of this research is finance ratio analysis to finance performance of PT Angkasa Pura II (Persero), period 2017-2019. The aim of this research is to compare company finance performance, which is measured by finance ratio analysis, which consist of liquidity ratio (current ratio, quick ratio, and cash ratio). Solvability ratio (Debt to Asset Ratio, Debt to equity ratio, Long term debt to equity ratio, and Time interest Earned Ratio), Activity Ratio (Working Capital Turn Over, Fixed Asset Turn Over, Total Asset Turn Over) and Profitability Ratio (Net Profit Margin, Operating Profit Margin, Return On Asset, Return On Equity, Earning Per Share). The Object of this research is PT Angkasa Pura II (Persero). The Kind Of this research is descriptive research. The Focus of this research is the company finance report which consist of balance report and profit and loss report on 2017-2019. The source of data being used is secondary data taken from
\end{abstract}


the website www.angkasapura2.co.id. Data analysis used in this research is descriptive analysis using finance ratio analysis. The result of this research will show finance activity of PT Angkasa Pura II (Persero) period 2017-2019 which consist of Ratio of liquidity, Solvability, Activity, and Profitability.

Keyword : Liquidity Ratio, Solvability Ratio, Activity Ratio, Profitability Ratio and finance performance

\section{A. PENDAHULUAN}

Baik buruknya kinerja keuangan suatu perusahaan dapat dilihat dari laporan keuangan perusahaan beberapa periode yang dilaporkannya. Laporan keuangan perusahaan dapat digunakan untuk melihat dan mengetahui perkembangan suatu perusahaan. Menurut Munawir (2007) laporan keuangan adalah hasil dari proses berkomunikasi antara data keuangan atau aktivitas suatu perusahaan dengan pihak-pihak yang bersangkutan dengan data atau aktivitas perusahaan tersebut. Laporan keuangan menyediakan informasi yang dibutuhkan oleh pihak-pihak yang berkepentingan, baik pihak internal maupun eksternal (investor). Pihak-pihak yang berkepentingan perlu mengetahui kondisi keuangan perusahaan untuk dapat menilai kinerja perusahaan. Laporan keuangan perusahaan sangat bermanfaat bagi masyarakat, investor, pemegang saham dan manajemen dalam pengambilan keputusan dan pengembangan asset yang dimiliki. Perkembangan perusahaan sangat bergantung pada modal yang ditanamkan oleh investor, sehingga perusahaan harus memiliki kinerja yang baik agar mendapatkan kepercayaan dari investor untuk menanamkan modalnya pada perusahaan.

Kondisi keuangan diketahui dari laporan keuangan perusahaan yang terdiri dari neraca, laporan laba-rugi, laporan perubahan ekuitas, dan laporan arus kas. Dari laporan keuangan saja belum dapat memberikan informasi yang tepat sebelum dilakukan analisis atas laporan keuangan. Sehingga diperlukan suatu analisis lebih jauh mengenai rasio keuangan dalam laporan keuangan. Kinerja perusahaan yang baik dapat membantu manajemen dalam mencapai tujuan perusahaan.

Gambaran tentang posisi keuangan dapat diketahui dengan menganalisis laporan keuangan. Neraca mencerminkan nilai aktiva, utang dan modal pada suatu 
periode tertentu, sedangkan laporan laba-rugi menunjukan biaya, pendapatan dan laba rugi perusahaan yang dicapai dalam suatu periode tertentu. Hasil analisis laporan keuangan membantu untuk menginterpretasikan berbagai hubungan kunci dan pertimbangan mengenai potensi keberhasilan pada perusahaan di masa mendatang.

Salah satu cara yang dipakai untuk menilai kinerja perusahaan untuk mengambil keputusan investasi adalah melalui analisis rasio keuangan. Beberapa rasio yang dapat digunakan dalam analisis laporan keuangan antara lain : rasio likuiditas, rasio solvabilitas, rasio aktivitas dan rasio profitabilitas. Satu rasio saja tidak cukup untuk memberi penilaian tentang kondisi keuangan serta kinerja perusahaan, maka dari itu perlu digunakan berbagai macam rasio.

\section{B. KAJIAN TEORI}

\section{Pengertian Laporan Keuangan}

Afriyeni (2008) mengemukakan bahwa laporan keuangan merupakan hasil akhir perhitungan akuntansi pada setiap akhir periode, perhitungan tersebut diantaranya yaitu proses identifikasi dan pengukuran data yang relevan, proses pencatatan transaksi yang dilakukan oleh perusahaan sampai hasil akhir yaitu proses perhitungan laporan keuangan. Laporan keuangan dapat berfungi sebagai alat informasi antara perusahaan dengan para investor dan pihak yang berkepentingan.

Dalam mengukur perkembangan suatu perusahaan dapat diketahui dengan melakukan pengukuran laporan keuangan. Pengukuran laporan keuangan yang disajikan bermaksud dan bermanfaat bagi pengguna informasi untuk mengetahui kuat lemahnya suatu perusahaan.

\section{Pengertian Kinerja Keuangan}

Menurut Mulyadi (2001) Kinerja merupakan penilaian perilaku manusia dalam suatu organisasi untuk tercapainya tingkat prestasi atau hasil nyata yang positif. Kinerja keuangan adalah prestasi dibidang keuangan yang unsur-unsurnya berkaitan dengan pendapatan, pengeluaran, keadaan operasional secara keseluruhan, struktur utang dan hasil investasi. Penilaian kinerja keuangan 
berbeda dengan penilaian barang baik berwujud maupun tidak berwujud. Untuk melakukan analisis penilaian aset, cukup diperiksa objek aset secara fisik, kondisi ekonomi, dan fungsionalnya yang bersifat statis. Penilaian kinerja keuangan perusahaan dilakukan terutama untuk beberapa tujuan sehubungan dengan kegiatan seperti pengambilan alih perusahaan, pemberian kredit, perluasan usaha dan sebagainya.

\section{Tujuan Penilaian Kinerja Keuangan}

Mulyadi (2011) menjelaskan bahwa tujuan penilaian kinerja adalah untuk memotivasi karyawan dalam mencapai sasaran organisasi dan dalam mematuhi standar perilaku yang telah ditetapkan sebelumnya, agar membuahkan tingkat dan hasil yang diinginkan. Standar perilaku dapat berupa kebijakan manajemen atau rencana formal yang dituangkan dalam anggaran. Kinerja keuangan suatu perusahaan merupakan hasil dari serangkaian proses dengan mengorbankan berbagai sumber daya. Adapun salah satu parameter kinerja tersebut adalah laba yang termasuk dalam rasio keuangan.

\section{Manfaat Penilaian Kinerja Keuangan}

Manfaat penelitian kinerja keuangan adalah sebagai berikut :

a. Memberikan pemahaman yang lebih baik menegenai pengelolaan utang termasuk mengenai keadaan keuangan secara keseluruhan.

b. Mengidentifikasi lebih awal masalah keuangan yang timbul sebelum terlambat.

c. Mengidentifikasi masalah keuangan yang ada yang mungkin tidak disadari oleh perusahaan.

d. Memberikan gambaran nyata, mengenai kelebihan dan kekurangan keadaan keuangan dan cara pengelolaan piutang.

Menurut Mulyadi (2001), manfaat penilaian kinerja adalah sebagai berikut :

a. Untuk mengelola operasi organisasi secara efektif dan efisien melalui pemotivasian karyawan secara maksimal.

b. Untuk membantu pengambilan keputusan yang bersangkutan dengan karyawan seperti promosi, transfer dan pemberhentian. 
c. Untuk mengidentifikasi kebutuhan pelatihan dan pengembangan karyawan dan untuk menyediakan kriteria seleksi dan evaluasi program pelatihan karyawan.

d. Menyediakan umpan balik bagi karyawan mengenai bagaimana atasan mereka menilai kinerja mereka.

e. Menyediakan suatu dasar bagi distribusi penghargaan

\section{Pengertian Analisis Laporan Keuangan}

Menurut Dr.Kasmir, analisis laporan keuangan adalah prosedur akuntansi dan penilaian yang benar akan kondisi keuangan perusahaan yang sesungguhnya. Kondisi keuangan yang dimaksud adalah diketahuinya berapa jumlah harta (kekayaan), kewajiban (utang) serta modal (ekuitas) dalam neraca yang dimiliki. Kemudian utang serta modal (ekuitas) dalam neraca yang dimiliki, juga akan diketahui jumlah pendapatan yang diterima dan jumlah biaya yang dikeluarkan selama periode tertentu. Dengan demikian, dapat diketahui bagaimana hasil usaha (laba atau rugi) yang diperoleh selama periode tertentu dari laporan laba rugi yang disajikan.

\section{Manfaat Analisis Laporan Keuangan}

Bagi manajer atau pimpinan perusahaan,laporan keuangan sangat berguna membantu pelaksanaan, perencanaan, dan pengendalian jalannya operasi perusahaan.

a. Bagi investor, penanaman modal berkepentingan terhadap risiko dan hasil yang melekat atas pengembangan dari investasi yang mereka lakukan. Pemegang saham juga tertarik pada analisis laporan keuangan guna menilai kemampuan perusahaan untuk membayar deviden.

b. Bagi pemerintah, berkepentingan untuk dijadikan dasar penetapan pajak atau tujuan-tujuan lain dalam rangka perumusan kebijakan tertentu.

\section{Pengertian Analisis Rasio Keuangan}

Menurut Munawir (2007) analisis rasio adalah suatu metode analisis untuk mengetahui hubungan dari pos-pos tertentu dalam neraca atau laporan laba-rugi 
secara individual atau kombinasi dari kedua laporan tersebut. Selain itu menurut Sundjaja dan Barlian (2003), analisis laporan keuangan adalah suatu metode perhitungan dan interpretasi rasio keuangan untuk menilai kinerja dan status suatu perusahaan.

Berdasarkan beberapa pendapat diats, maka dapat dikatakan bahwa pengertian analisis laporan keuangan adalah suatu alat yang digunakan untuk menjelaskan atau memberikan gambaran tentang keadaan atau posisi keuangan perusahaan.

\section{Jenis-jenis Analisis Rasio Keuangan}

\section{a. Rasio Likuiditas}

Rasio likuiditas adalah rasio yang digunakan untuk mengukur kemampuan perusahaan dalam menjamin kewajiban-kewajiban lancarnya atau membayar hutang jangka pendeknya (kurang drai 1 tahun) dalam waktu yang tidak terlalu lama. Rasio inilah yang dapat digunakan untuk mengukur seberapa likuidnya (cairnya) suatu perusahaan. Jika perusahaan mampu memenuhi kewajibannya berarti perusahaan tersebut likuid, sedangkan jika perusahaan tidak mampu memenuhi kewajibannya berarti perusahaan tersebut tidak likuid. Rasio ini terbagi menjadi 3 bagian yaitu:

\section{1) Current ratio (Rasio lancar)}

yaitu rasio yang mengukur kemampuan perusahaan dalam melunasi hutang jangka pendek dengan menggunakan aktiva lancar. Dengan kata lain, seberapa banyak aktiva lancar yang tersedia untuk menutupi kewajiban jangka pendek yang akan segera jatuh tempo.

Rumus : Current Ratio $=\frac{\text { Aktiva lancar }}{\text { Utang lancar }} \times 100 \%$

\section{2) Quick ratio (Rasio sangat lancar)}

yaitu rasio yang mengukur kemampuan perusahaan dalam memenuhi atau membayar hutang lancar dengan menggunakan aktiva lancar tanpa memperhitungkan persediaan. 
Rumus : Quick Ratio $=\frac{\text { Aktiva lancar }- \text { Persediaan }}{\text { Utang lancar }}$

\section{3) Cash ratio (Rasio kas)}

Merupakan rasio yang digunakan untuk mengukur seberapa besar uas kas yang tersedia untuk membayar hutang. Ketersediaan uang kas dapat ditunjukkan dari tersedianya dana kas atau yang setara dengan kas seperti rekening giro atau tabungan dari bank.

Rumus : Cash Ratio $=\frac{\text { Kas }}{\text { Utang lancar }}$

\section{b. Rasio Solvabilitas}

Menurut Dr.Kasmir, rasio solvabilitas atau leverage ratio merupakan rasio yang digunakan untuk mengukur sejauh mana aktiva perusahaan dibiayai dengan utang. Artinya berapa besar beban utang yang ditanggung perusahaan dibandingkan dengan aktivanya. Dalam arti luas dikatakan bahwa rasio solvabilitas digunakan untuk mengukur kemampuan perusahaan untuk membayar seluruh kewajibannya, baik jangka pendek maupun jangka panjang apabila perusahaan dibubarkan (dilikuidasi). Adapun jenis- jenis rasio yang ada dalam rasio solvabilitas antara lain :

\section{1) Debt to Asset Ratio (Debt Rasio)}

Merupakan rasio utang yang digunakan untuk mengukur perbandingan antara total utang dengan total aktiva. Dengan kata lain, seberapa besar aktiva perusahaan dibiayai oleh utang atau seberapa besar utang perusahaan berpengaruh terhadap pengelolaan aktiva.

Rumus : Debt to Asset Ratio $=\frac{\text { Total Debt }(\text { total utang })}{\text { Total Asset }(\text { total aset })} \times 100 \%$

\section{2) Debt to Equity Ratio}

Merupakan rasio yang digunakan untuk menilai utang dengan ekuitas. Rasio ini diukur dengan cara membandingkan antara seluruh utang,termasuk utang lancar dengan seluruh ekuitas. Rasio ini berguna 
untuk mengetahui jumlah dana yang disediakan peminjam (kreditor) dengan pemilik perusahaan.

Rumus : Debt to Equity Ratio $=\frac{\text { Total Debt }(\text { total utang })}{\text { Total Equity }(\text { total ekuitas })} \times 100 \%$

\section{3) Long Term Debt to Equity Ratio (LTDTER)}

Merupakan rasio antara utang jangka panjang dengan modal sendiri. Tujannya adalah untuk mengukur berapa bagian dari setiap rupiah modal sendiri yang dijadikan jaminan utang jangka panjang dengan cara membandingkan antara utang jangka panjang dengan modal sendiri yang disediakan oleh perusahan.

Rumus : LTDTER $=\frac{\text { Long Term Debt }}{\text { Equity (ekuitas) }} \times 100 \%$

\section{4) Time Interest Earned}

Menurut J. Fred Weston, Time Interest Earned merupakan rasio untuk mencari jumlah kali perolehan bunga. Rasio ini diartikan oleh James C Van Horne juga sebagai kemampuan perusahaan untuk membayar biaya bunga.

Rumus : Time Interest Earned $=\frac{E B I T}{\text { Biaya Bunga (Interest) }} \times 100 \%$

Atau

Time Interest Earned $=\frac{\text { EBIT+Biaya Bunga }}{\text { Biaya Bunga }(\text { Interest })} \times 100 \%$

\section{c. Rasio Aktivitas}

Menurut Kasmir “Analisis Laporan Keuangan” Rasio aktivitas merupakan rasio yang digunakan untuk mengukur efektivitas perusahaan dalam menggunakan aktiva yang dimilikinya dapat dikatakan pula rasio ini 
digunakan untuk mengukur tingkat efisiensi (efektivitas) pemanfaatan sumber daya perusahaan. Jenis- jenis rasio yang ada dalam rasio aktivitas antara lain :

\section{1) Perputaran aktiva (Total Assets Turnover)}

Total assets turnover merupakan perbandingan antara penjualan dengan total aktiva suatu perusahaan dimana rasio ini menggambarkan kecepatan perputarannya total aktiva dalam satu periode tertentu.

Rumus : Total Assets Turnover $=\frac{\text { Penjualan }}{\text { Total Aktiva }}$

\section{2) Perputaran modal kerja (Working Capital Turnover)}

Perputaran modal kerja merupakan perbandingan antara penjualan dengan modal kerja bersih. Dimana modal kerja bersih adalah aktiva lancar dikurangi utang lancar. Perputaran modal kerja merupakan rasio mengukur aktivitas bisnis terhadap kelebihan aktiva lancar atas kewajiban lancar serta menunjukkan banyaknya penjualan (dalam rupiah) yang dapat diperoleh perusahaan untuk tiap rupiah modal kerja (Sawir, 2009:16).

Rumus : $W C T=\frac{\text { Penjualan }}{\text { Modal Kerja Bersih }}=\frac{\text { Penjualan }}{\text { Aktiva lancar-utang lancar }}$

\section{3) Perputaran aktiva tetap (Fixed Assets Turnover)}

Rasio ini merupakan perbandingan antara penjualan dengan aktiva tetap. Fixed assets turn over mengukur efektivitas penggunaan dana yang tertanam pada harta tetap seperti pabrik dan peralatan, dalam rangka menghasilkan penjualan, atau berapa rupiah penjualan bersih yang dihasilkan oleh setiap rupiah yang diinvestasikan pada aktiva tetap (Sawir, 2003:17).

Rumus : Perputaran aktiva tetap $=\frac{\text { Penjualan }}{\text { Aktiva tetap }}$

\section{d. Rasio Profitabilitas}

Menurut Kasmir dalam bukunya yang berjudul Analisis Laporan Keuangan, Rasio profitabilitas merupakan rasio untuk menilai kemampuan perusahaan dalam mencari keuntungan. Rasio ini juga memberikan ukuran 
tingkat efektivitas manajemen suatu perusahaan. Adapun jenis-jenis rasio profitabilitas adalah sebagai berikut :

\section{1) Margin Laba Bersih (Net Profit Margin)}

Menurut Bastian dan Suhardjono, pengertian NPM adalah perbandingan antara laba bersih dengan penjualan. Dengan semakin besar tingkat Net Profit Margin maka kinerja perusahaan dapat semakin produktif.

Rumus : NPM $=\frac{\text { Laba Bersih Setelah Pajak }}{\text { Pendapatan }} \times 100 \%$

\section{2) Margin Laba Operasi (Operation Profit Margin)}

Operating profit margin atau Margin laba operasi adalah rasio profitabilitas yang mengukur seberapa banyak laba yang dihasilkan perusahaan dari satu rupiah penjualan, setelah membayar biaya operasional, tetapi sebelum membayar bunga atau pajak. Ini dihitung dengan membagi laba operasi perusahaan dengan penjualan bersihnya

Rumus : $O P M=\frac{\text { Laba Operasi }}{\text { Pendapatan }} \times 100 \%$

\section{3) ROA (Return On Assets)}

Return on Assets atau dalam bahasa Indonesia sering disebut dengan Tingkat Pengembalian Aset adalah rasio profitabilitas yang menunjukan persentase keuntungan (laba bersih) yang diperoleh perusahaan sehubungan dengan keseluruhan sumber daya atau rata-rata jumlah asset.

Rumus : $R O A=\frac{\text { Laba Bersih Setelah Pajak }}{\text { Total Assets }} \times 100 \%$

\section{4) ROE (Return on Equity)}

Rasio ini untuk mengukur laba bersih yang sudah dikenai pajak dengan modal sendiri, yang tujuannya untuk mengetahui efisiensi penggunaan modal.

Rumus : $R O E=\frac{\text { Earning After Interest and Tax }}{\text { Equity }}$ 


\section{5) Laba per Lembar Saham (Earning per share of Common Stock)}

Rasio ini untuk mengukur kinerja manajemen untuk mencapai keuntungan bagi para pemegang saham yang ada diperusahaan. Rumus : Laba Per Lembar Saham $=\frac{\text { Laba saham biasa }}{\text { Saham biasa beredar }}$

\section{METODE PENELITIAN}

Penelitian ini bertujuan untuk mengetahui gambaran mengenai kinerja keuangan PT. Angkasa Pura II tiap periode (2017-2019) dilihat dari rasio keuangan perusahaan berupa neraca, dan laporan laba-rugi. Sehingga dari gambaran tersebut dapat diketahui bagaimana perbandingan kinerja dari PT. Angkasa Pura II dari setiap periode.

Jenis penelitian ini menggunakan metode analisis deskriptif. Menurut Sukmadinata, 2006 (dalam Gandhi, 2015) penenlitian deskriptif adalah suatu bentuk penelitian yang berupa gambaran atau pendeskripsian dari hasil penelitian. Melalui penelitian deskriptif, peneliti berusaha mendeskripsikan peristiwa dan kejadian yang menjadi pusat perhatian tanpa memberikan perlakuan khusus terhadap peristiwa tersebut. Penelitian deskritif yaitu penelitian yang berusaha untuk menuturkan pemecahan masalah yang ada sekarang berdasarkan data-data.

Ditinjau dari sumber dan jenis datanya, Sumber data yang dipergunakan dalam penelitian berupa data sekunder yang bersumber dari laporan tahunan (annual report) PT. Angkasa Pura II (Persero) selama periode 2017 - 2019. Jenis data yang digunakan adalah berupa laporan keuangan (neraca dan laporan laba rugi). Jenis data yang akan digunakan dalam penelitian ini adalah data kuantitatif, yaitu data yang disajikan dalam bentuk angka - angka yang diperoleh dari situs resmi. Dalam penelitian ini data kuantitatif di peroleh dari web resmi perusahaan yaitu www.angkasapura2.co.id.

\section{HASIL DAN PEMBAHASAN}

Tabel 1 Hasil Analisis Rasio Likuiditas 


\begin{tabular}{|c|c|c|c|}
\hline Tahun & Current Ratio & Quick Ratio & Cash Ratio \\
\hline $\mathbf{2 0 1 7}$ & $1,8 \mathrm{Kali}$ & $1,8 \mathrm{Kali}$ & $147,6 \%$ \\
\hline $\mathbf{2 0 1 8}$ & $1,2 \mathrm{Kali}$ & $1,2 \mathrm{Kali}$ & $74,8 \%$ \\
\hline $\mathbf{2 0 1 9}$ & $1,1 \mathrm{Kali}$ & $1,1 \mathrm{Kali}$ & $64,1 \%$ \\
\hline
\end{tabular}

Jika rata-rata industry untuk current ratio adalah dua kali, maka artinya keadaan perusahaan dalam kondisi baik. Sedangkan jika kita lihat hasil perhitungan current ratio dari PT Angkasa Pura II hasilnya 3 tahun berturut-turut kurang dari dua kali, untuk tahun 2017 sebesar 1,8 kali dan setiap tahun mengalami penurunan. Tahun 2018 turun sebesar 0,6 dan tahun 2019 turun 0,1. Maka ini artinya kondisi perusahaan PT Angkasa Pura II dalam membayar kewajiban dengan menggunakan aktiva lancar kurang baik karena rasionya masih di bawah rata-rata industry, hal ini dapat dikatakan aktiva lancar lil-liquid.

Pada umumnya quick ratio yang paling bagus adalah 1:1, maka dilihat dari hasil perhitungan diatas, quick ratio perusahaan PT Angkasa Pura II masih terbilang baik namun mengalami penurunan setiap tahunnya. Ini menandakan bahwa kemampuan perusahaan dalam membayar kewajibannya semakin memburuk, namun masih memiliki kemampuan untuk membayar atau dapat dikatakan perusahaan masih likuid. Jika dilihat dari tabel, penurunan rasio ini diakibatkan oleh menurunnya aktiva lancar terutama pada akun kas yang setiap tahunnya berkurang. Pada tahun 2017 kas memiliki jumlah sebesar Rp6,05 triliun lalu menurun sebesar Rp2,26 triliun dan pada tahun 2018 kas mengalami penurunan kembali sebesar Rp3,7 miliar, maka pada tahun 2019 kas hanya berjumlah sebesar Rp3,42 triliun. Dan juga penurunan rasio ini diakibatkan oleh meningkatnya hutang lancar terutama pada utang usaha yang mengalami peningkatan sebesar Rp164,5 miliar pada tahun 2017 dan pada tahun 2018 meningkat sebesar Rp159,5 miliar, maka pada tahun 2019 utang usaha berjumlah sebesar Rp408,4 miliar, diikuti oleh peningkatan liabilitas dana pensiun yang mengalami peningkatan setiap tahunnya. Tahun 2017 liabilitas dana pensiun sebesar Rp21,6 miliar lalu meningkat sebesar Rp7,1 miliar menjadi Rp28,7 miliar dan meningkat kembali sebesar Rp1,9 miliar maka tahun 2019 liabilitas dana pension sebesar Rp30,6 miliar. Liabilitas imbalan kerja jangka pendek pun 
mengalami peningkatan sebesar Rp43,2 miliar pada tahun 2018 menjadi sebesar Rp216,9 miliar dan 2019 meningkat sebesar Rp23,2 miliar menjadi sebesar Rp240,2 miliar. Begitu juga dengan jangka pendek utang bank pun meningkat sebesar Rp201,8 miliar pada tahun 2018 dan tahun 2019 meningkat sebesar R p250,1 miliar.

Cash ratio untuk rata-rata industri yaitu sebesar 50\%, maka jika diata 50\% itu artinya keadaan perusahaan lebih baik dari perusahaan lain. Dilihat dari hasil perhitungan cash ratio PT Angkasa Pura II rata-rata jumlahnya diatas 50\% yang menandakan bahwa perusahaan ini dalam keadaaan baik atau likuid. Namun, jika dilihat berdasarkan perbandingan setiap tahunnya yang hasilnya selalu mengalami penurunan, itu artinya perusahaan ini semakin tahun semakin menurun kondisi perusahaannya. Pada tahun 2017 cash ratio yang dihasilkan sebesar 147,6\%, maka cash ratio yang terlalu tinggi seperti ini juga kurang baik karena itu artinya terdapat dana yang menganggur atau tidak atau belum digunakan secara optimal oleh perusahaan dalam menghasilkan laba.

Analisis Rasio Solvabilitas PT. Angkasa Pura II

Tabel 2 Hasil Analisis Rasio Solvabilitas

\begin{tabular}{|c|c|c|c|c|}
\hline Tahun & DAR & DER & LTDTER & TIE \\
\hline $\mathbf{2 0 1 7}$ & $32 \%$ & $48 \%$ & $27,9 \%$ & 10,2 Kali \\
\hline $\mathbf{2 0 1 8}$ & $39 \%$ & $64 \%$ & $42,9 \%$ & 5,9 Kali \\
\hline $\mathbf{2 0 1 9}$ & $44 \%$ & $80 \%$ & $58,1 \%$ & 2,1 Kali \\
\hline
\end{tabular}

Debt to asset ratio (DAR) mengalami peningkatan setiap tahunnya. Pada tahun 2017 sebesar 32\% Rasio ini menunjukkan bahwa 32\% pendanaan perusahaan dibiayai dengan utang untuk tahun 2017. Artinya, bahwa setiap Rp 100 pendanaan perusahaan, Rp 32 dibiayai dengan utang dan Rp 68 disediakan oleh pemegang saham. Kemudian pada tahun 2018 meningkat menjadi 39\%, rasio ini menunjukkan bahwa $39 \%$ pendanaan perusahaan dibiayai dengan utang untuk tahun 2018. Artinya, bahwa setiap Rp 100 pendanaan perusahaan, Rp 39 dibiayai dengan utang dan Rp 61 disediakan oleh pemegang saham . Kemudian pada tahun 
2019 meningkat menjadi 44\%, rasio ini menunjukkan bahwa 44\% pendanaan perusahaan dibiayai dengan utang untuk tahun 2019. Artinya, bahwa setiap Rp 100 pendanaan perusahaan, Rp 44 dibiayai dengan utang dan Rp 56 disediakan oleh pemegang saham. Selama 3 tahun terakhir ini rasio DAR (Debt to asset ratio) menunjukkan peningkatan yang artinya semakin banyak pendanaan berasal dari utang. Terdapat kekhawatiran perusahaan akan sulit mendapatkan tambahan pinjaman karena akan semakin sulit menutupi utangnya dengan aktiva yang dimilikinya.

Debt to equity ratio (DER) mengalami peningkatan setiap tahunnya. Pada tahun 2017 sebesar $48 \%$ hal ini menunjukkan bahwa setiap rupiah dari total hutang perusahaan mampu dijamin dengan Rp 48 dari modal sendiri atau dapat dikatakan bahwa kemampuan perusahaan dalam menutup seluruh hutangnya melalui modal sendiri adalah 42\% . Kemudian pada tahun 2018 juga mengalami kenaikan sebesar $16 \%$ dari tahun sebelumnya yang hanya $48 \%$ meningkat menjadi $64 \%$, ini berarti bahwa setiap satu rupiah dari total hutang perusahaan mampu dijamin dengan Rp 64 dari modal sendiri atau kemampuan perusahaan dalam menutup seluruh hutangnya melalui modal sendiri adalah 64\%. Kemudian pada tahun 2019 juga mengalami kenaikan sebesar 16\% dari tahun sebelumnya yang hanya $64 \%$ meningkat menjadi $80 \%$, ini berarti bahwa setiap satu rupiah dari total hutang perusahaan mampu dijamin dengan $\mathrm{Rp} 80$ dari modal sendiri atau kemampuan perusahaan dalam menutup seluruh hutangnya melalui modal sendiri adalah $80 \%$. Selama 3 tahun terakhir rasio DER (Debt to equity ratio) menunjukkan peningkatan ini menunjukkan komposisi total hutang semakin besar dibanding dengan total modal sendiri, sehingga berdampak semakin besar beban perusahaan terhadap pihak luar (kreditur). Meningkatnya beban terhadap kreditur menunjukkan sumber modal perusahaan dapat mengurangi jumlah laba yang diterima perusahaan.

Berdasarkan perhitungan di atas, Long Term Debt to Equity Ratio (LTDTER) PT. Angkasa Pura II pada tahun 2017 sebesar 27,9\% hal ini berarti utang jangka panjang perusahaan besarnya adalah 27,9\% dari nilai ekuitas yang dimiliki perusahaan,artinya sebesar Rp.0,27 dari setiap rupiah modal sendiri menjadi jaminan utang jangka panjang. Pada tahun 2018 sebesar 42,9\% hal ini 
berarti utang jangka panjang perusahaan besarnya adalah 42,9\% dari nilai ekuitas yang dimiliki perusahaan,artinya sebesar Rp.0,42 dari setiap modal sendiri menjadi jaminan utang jangka panjang. Dan pada tahun 2019 sebesar 58,1\% hal ini berarti utang jangka panjang perusahaan besarnya adalah 58,1\% dari nilai ekuitas yang dimiliki perusahaan,artinya sebesar Rp.0,58 dari setiap modal sendiri menjadi jaminan utang jangka panjang. Long Term Debt to Equity Ratio (LTDTER) PT. Angkasa Pura II dari tahun 2017 hingga 2019 mengalami kenaikan, hal itu dikarenakan setiap tahun ekuitas mengalami kenaikan walaupun diikuti pula dengan kenaikan utang jangka panjang dan hal itu jug dikarenakan total ekuitas jauh lebih tinggi dibandingkan dengan utang jangka panjangnya. Oleh karena itu dapat dikatakan bahwa perusahaan baik, karena perusahaan lebih banyak menggunakan modal sendiri dibandingkan menggunakan utang jangka panjang.

Berdasarkan perhitungan di atas, Time interest Earned Ratio (TIE) PT. Angkasa Pura II pada tahun 2017 sebesar 10,2 hal ini berarti pendapatan atau laba operasi perusahaan 10,2 kali lebih besar dari biaya beban bunga tahunannya,dengan kata lain berarti pendapatan atau laba perusahaan mampu membayar total beban bunga hingga 10.2 kali lipat. Pada tahun 2018 sebesar 5,9 hal ini berarti pendapatan atau laba operasi perusahaan 5,9 kali lebih besar dari biaya beban bunga tahunannya,dengan kata lain berarti pendapatan atau laba perusahaan mampu membayar total beban bunga hingga 5,9 kali lipat. Dan pada tahun 2019 sebesar 2,1 hal ini berarti pendapatan atau laba operasi perusahaan 2,1 kali lebih besar dari biaya beban bunga tahunannya, dengan kata lain berarti pendapatan atau laba perusahaan mampu membayar total beban bunga hingga 2,1 kali lipat. Time Interest Earned Ratio (TIE) PT. Angkasa Pura II dari tahun 2017 hingga 2019 mengalami penurunan, hal itu dikarenakan setiap tahun biaya beban bunga mengalami kenaikan sedangkan pendapatan atau laba mengalami penurunan, tetapi total pendapatan atau laba masih lebih tinggi jika dibandingkan dengan beban bunga walaupun mengalami penurunan. Jadi walaupun dari setiap tahun mengalami penurunan tetapi perusahaan masih mampu untuk menutupi atau membayar beban bunga. Dan dapat dikatakan pula bahwa perusahaan masih aman dan tidak terlalu berisiko karena rasionya masih berada diatas 1,5 . 
Analisis Rasio Aktivitas PT. Angkasa Pura II

Tabel 3 Hasil Analisis Rasio Aktivitas

\begin{tabular}{|c|c|c|c|}
\hline Tahun & $\begin{array}{c}\text { Total Asset } \\
\text { Turnover }\end{array}$ & $\begin{array}{c}\text { Working Capital } \\
\text { Turnover }\end{array}$ & $\begin{array}{c}\text { Fixed Asset } \\
\text { Turnover }\end{array}$ \\
\hline $\mathbf{2 0 1 7}$ & 0,248 Kali & $2,5 \mathrm{Kali}$ & $0,321 \mathrm{Kali}$ \\
\hline $\mathbf{2 0 1 8}$ & 0,285 Kali & $10,84 \mathrm{Kali}$ & 0,377 Kali \\
\hline $\mathbf{2 0 1 9}$ & 0,252 Kali & $17,75 \mathrm{Kali}$ & $0,291 \mathrm{Kali}$ \\
\hline
\end{tabular}

Berdasarkan perhitungan Total Asset Turn Over PT Angkasa Pura II dapat dilihat dari perputaran aktiva total, kondisi PT Angkasa Pura II sangat tidak menggembirakan karena terjadi penurunan rasio dari tahun 2018 ke tahun 2019. Dari yang sebelumnya mengalami kenaikan dari tahun 2017 ke tahun 2018. Kemudian jika dibandingkan dengan rata-rata industri untuk total asset turn over, yaitu 5 kali, berarti PT Angkasa Pura II diharapkan meningkatkan lagi penjualannya atau mengurangi sebagian aktivitas yang kurang produktif. Dan diharapkan manajemen dapat memanfaatkan setiap rupiah aktiva untuk menghasilkan penjualan.

Berdasarkan perhitungan Working Capital Turn Over PT Angkasa Pura II dapat dilihat rasio perputaran modal kerja dari tahun 2017-2019 selalu mengalami kenaikan. Hal ini menunjukan ada kemajuan yang diperoleh manajemen. Perusahaan makin efisien, yang pada akhirnya rentabilitas meningkat. Namun jika rata-rata industry untuk perputaran modal kerja adalah 15 kali, maka keadaan perusahaan untuk tahun 2017 dan tahun 2018 dinilai kurang baik karena masih dibawah rata-rata industri. Sedangkan untuk tahun 2019 dinilai baik karena sudah diatas rata-rata industri.

Berdasarkan perhitungan Fixed Asset Turn Over PT Angkasa Pura II dapat dilihat Perputaran aktiva tetap PT Angkasa Pura II sangat tidak menggembirakan karena terjadi penurunan rasio dari tahun 2018 ke tahun 2019. Dari yang sebelumnya mengalami kenaikan dari tahun 2017 ke tahun 2018. Lebih lagi jika dibandingkan dengan rata-rata industry untuk total asset turn over, yaitu 5 kali, berarti perusahaan belum mampu memaksimalkan kapasitas aktiva tetap yang 
dimiliki jika dibandingkan dengan perusahaan lain yang sejenis. Dan diharapkan manajemen dapat mengefektifkan penggunaan aktiva tetap.

Analisis Rasio Profitabilitas PT. Angkasa Pura II

Tabel 4 Hasil Analisis Rasio Profitabilitas

\begin{tabular}{|c|c|c|c|c|c|}
\hline Tahun & NPM & OPM & ROA & ROE & EPS \\
\hline $\mathbf{2 0 1 7}$ & $24,78 \%$ & $36 \%$ & $6,16 \%$ & $9,12 \%$ & $29 \%$ \\
\hline $\mathbf{2 0 1 8}$ & $17,49 \%$ & $27,70 \%$ & $4,98 \%$ & $8,17 \%$ & $28 \%$ \\
\hline $\mathbf{2 0 1 9}$ & $9,09 \%$ & $22,04 \%$ & $2,29 \%$ & $4,12 \%$ & $6 \%$ \\
\hline
\end{tabular}

Pada Tabel 4 dapat diketahui bahwa Margin Laba Bersih atau Net Profit Margin yang diperoleh oleh PT Angkasa Pura II (Persero) adalah pada tahun 2017 sebesar 24.78\%, pada tahun 2018 sebesar 20.15\%, dan pada tahun 2019 sebesar $9.09 \%$. Berdasarkan teori yang sudah dijelaskan bahwa pada rasio profitabilitas menghasilkan nilai mendekati angka 1 menunjukkan bahwa perusahaan ini baik atau sehat, begitu juga sebaliknya jika hasil rasio mendekati angka 0 maka belum maksimal atau tidak sehat. Berdasarkan hasil perhitungan analisis Net Profit Margin maka dapat diperoleh gambaran bahwa pada tahun 2017 Net Profit Margin sebesar 24.78\%. Ini berarti bahwa setiap Rp. 1,- pendapatan akan menghasilkan keuntungan Neto sebesar Rp. 0.2478. Kemudian pada tahun 2018 Net Profit Margin mengalami penurunan sebesar 7.29\%, Hal ini terlihat dari tahun 2017 Net Profit Margin sebesar 24.78\%. menjadi 17.49\% pada tahun 2018. Ini berarti setiap Rp. 1,- pendapatan akan menghasilkan keuntungan neto sebesar Rp. 0.1749. Penurunan ini terjadi disebabkan karena adanya penurunan laba bersih setelah pajak yang dimana pada tahun 2017 sebesar Rp.2,009,855,743,920 menjadi Rp. 1,957,941,929,002 pada tahun 2018. Dan diikuti dengan adanya kenaikan penjualan yaitu dari Rp. 8,110,401,907,955 pada tahun 2017 menjadi Rp. 11,193,309,587,202 pada tahun 2018. Pada tahun 2019 pula Net Profit Margin kembali mengalami penurunan sebesar $8.40 \%$. Hal ini terlihat dari tahun 2018 Net Profit Margin sebesar 17.49\% menjadi 9.09\% pada tahun 2019. Ini berarti setiap Rp. 1,- pendapatan akan menghasilkan keuntungan neto sebesar Rp. 
0.0909,- Penurunan ini terjadi disebabkan karena adanya penurunan laba bersih setelah pajak yang dimana pada tahun 2018 sebesar Rp. 1,957,941,929,002 menjadi Rp. 1,007,256,149,471 pada tahun 2019. Dan diikuti dengan adanya kenaikan penjualan yaitu dari Rp. 11,193,309,587,202 pada tahun 2018 menjadi 11,084,234,115,664 pada tahun 2019. Rata-rata net profit margin PT. Angkasa Pura II (Persero) adalah sebesar 17.12\% artinya bahwa laba bersih sesudah pajak yang di capai adalah sebesar $17.12 \%$ dari volume penjualan. Tetapi hasil tersebut masih jauh dibandingkan dengan standar rasio industri Net Profit Margin yaitu sebesar 20\%, sehingga dapat dikatakan bahwa kinerja PT. Angkasa Pura II (Persero) selama tahun 2017-2019 berdasarkan Net Profit Margin dinilai cukup baik. Dengan demikian dapat diketahui bahwa dalam kurun waktu 2017- 2019 Net profit margin mengalami fluktuasi. Hal ini dikarenakan penjualan dan laba bersih setelah pajak juga mengalami kenaikan dan penurunan. Selain laba bersih setelah pajak dan penjualan, faktor penting yang harus diperhatikan adalah biaya usaha. Meningkatkan penjualan dengan menekan biaya atau memperkecil operational expenses, dapat meningkatkan profitabilitas perusahaan. Semakin tinggi net profit margin maka semakin tinggi pula profitabilitas dengan ketentuan bahwa peningkatan penjualan dalam perusahaan harus disertai dengan pengontrolan operasi expenses.

Pada Tabel 4 dapat diketahui bahwa Margin Laba Operasi atau Operation Profit Margin yang diperoleh oleh PT Angkasa Pura II (Persero) adalah pada tahun 2017 sebesar 36\%, pada tahun 2018 sebesar 31.66\%, dan pada tahun 2019 sebesar 22.04\%. Berdasarkan teori yang sudah dijelaskan bahwa pada rasio profitabilitas menghasilkan nilai mendekati angka 1 menunjukkan bahwa perusahaan ini baik atau sehat, begitu juga sebaliknya jika hasil rasio mendekati angka 0 maka belum maksimal atau tidak sehat. Berdasarkan hasil perhitungan Margin Laba Operasi atau Operation Profit Margin maka dapat diperoleh gambaran bahwa pada tahun 2017 OPM nya sebesar 36\%, ini berarti bahwa setiap Rp. 1,- pendapatan akan menghasilkan keuntungan neto sebesar Rp. 0,36. Pada tahun 2015 mengalami penurunan dari 36\% di tahun 2017 menjadi 31.66\% di tahun 2018. Ini berarti bahwa setiap Rp.1,- pendapatan akan menghasilkan keuntungan Neto sebesar Rp. 0,3166. Pada tahun 2019 juga mengalami penurunan 
yang lebih ekstrim yaitu dari 31.66\% di tahun 2018 menjadi $22.04 \%$ di tahun 2019. Ini juga menunjukan bahwa setiap Rp.1,- pendapatan akan mendapatkan keuntungan neto sebesar Rp. 0,2204. Penurunan nilai Margin Laba Operasi ini yang terjadi setiap tahunnya pada PT Angkasa Pura II (Persero) dikarenakan biaya-biaya operasional yang semakin tinggi tiap tahunnya meskipun pendapatan semakin naik setiap tahunnya. Dilihat dari Laporan Keuangan PT Angkasa Pura II (Persero) biaya operasional setiap tahunnya semakin meningkat pada tahun 2017 biaya operasional bandara adalah sebesar Rp. 2.782.862.763.872 akan tetapi pada tahun 2018 meningkat dan mencapai sebesar Rp. 3. 588.457.636.265. Hal ini berpengaruh pada margin laba operasi karena pada tahun 2018 penumpang pesawat menurun dan disisi lain kebutuhan operasional bandara yang masih harus dipenuhi serta peningkatan harga biaya operasional setiap tahunnya. Dan pada tahun 2019 biaya operasional juga naik hingga 5.180.941.217.008. Hal ini dikarenakan pada tahun 2019 PT Angkasa Pura II (Persero) membuka bandarabandara baru yang artinya membutuhkan biaya operasional yang tidak sedikit, meskipun pada tahun ini tingkat pendapatannya lebih tinggi itu juga dikarenakan harga tiket pesawat pada 2019 naik hingga 20\% tetapi disamping itu penurunan penumpang juga turun hingga 18-20\% yang mana hal tersebut tidak menjadikan kondisi keuangan PT Angkasa Pura ini jauh lebih baik. Rata-rata Operation profit margin PT. Angkasa Pura II (Persero) adalah sebesar $28.58 \%$ artinya bahwa laba operasi yang di capai adalah sebesar $28.58 \%$ dari volume penjualan. Hasil tersebut sudah sangat baik bila dibandingkan dengan standar rasio industri Operation Profit Margin yaitu sebesar 10,8\%, sehingga dapat dikatakan bahwa kinerja PT. Angkasa Pura II (Persero) selama tahun 2017-2019 berdasarkan Operation Profit Margin dinilai sangat baik. Sejauh ini perkembangan PT Angkasa Pura II (Persero) ini bisa dikatakan sangat baik, karena pendapatan non aeronautika nya berjalan dengan baik sehingga perusahaan ini bisa mempertahankan pertumbuhan pendapatan.

Dilihat dari hasil perhitungan diatas, maka dapat kita lihat bahwa Return On Assets (ROA) tahun 2017 adalah sebesar 6.16\%. Hal ini berarti setiap Rp. 1,aktiva akan menghasilkan Rp. 0.0616. Kemudian pada tahun 2018 Return On Assets (ROA) mengalami penurunan sebesar $1.18 \%$. Hal ini terlihat dari pada 
tahun 2017 Return On Assets (ROA) sebesar 6.16\% dan menjadi 4.98\% pada tahun 2018. yang artinya pada tahun 2018 setiap Rp. 1,- aktiva akan menghasilkan Rp. 0.0498. Penurunan ini terjadi disebabkan karena adanya penurunan laba bersih setelah pajak yang dimana pada tahun 2017 sebesar Rp.2,009,855,743,920 menjadi Rp. 1,957,941,929,002 pada tahun 2018. Dan adanya kenaikan total aktiva dari Rp. 32,651,959,318,664 pada tahun 2017 menjadi Rp.39,318,360,267,063 pada tahun 2018. Pada tahun 2019 Return On Assets (ROA) mengalami penurunan kembali sebesar 2.69\%. Hal ini terlihat dari tahun 2017 Return On Assets (ROA) sebesar 4.98\% dan menjadi 2.29\% pada tahun 2019. Yang artinya pada tahun 2019 setiap Rp. 1 aktiva hanya menghasilkan Rp. 0.0229. Penurunan ini terjadi disebabkan karena adanya penurunan laba bersih setelah pajak yang dimana pada tahun 2018 sebesar Rp. 1,957,941,929,002 menjadi Rp. 1,007,256,149,471 pada tahun 2019. Dan adanya kenaikan total aktiva dari Rp. 39,318,360,267,063 pada tahun 2018 menjadi Rp.43,998,030,368,393 pada tahun 2019. Dengan demikian Return On Assets (ROA) pada 3 tahun terakhir (2017-2019) mengalami penurunan. Rata-rata return on assets PT. Angkasa Pura II (Persero) yaitu sebesar 4.48\%, artinya bahwa penghasilan bersih yang di peroleh adalah sebesar $4.48 \%$ dari total aktiva. Tetapi hasil tersebut masih jauh dibandingkan dengan standar rasio industri Return On Assets (ROA) yaitu sebesar 30\%, sehingga dapat dikatakan bahwa kinerja PT. Angkasa Pura II (Persero) selama tahun 2017-2019 berdasarkan Return On Assets (ROA) dinilai sangat kurang baik.

Perhitungan ROE pada tahun 2017 hingga 2019 menunjukan penurunan dari tingkat pengembalian investasi pada 2017 sebesar 9,12\% turun pada tahun 2018 menjadi 8,17\% dan turun kembali pada 2019 menjadi 4,12\%. Ini menunjukan ketidakmapuan manajemen untuk memperoleh ROE. ROE bisa dikatakan baik bila ROE itu sendiri lebih besar dari suku bunga bank. pada tahun 2017 suku bunga rata-rata sebesar 4,56 maka ROE pada tahun 2017 dapat dikatakan sehat karena lebih besar dari suku bunga bank sehingga pada tahun 2017 perusahaan dalam kondisi yang baik. kemudian pada tahun 2018 suku bunga bank rata-rata sebesar 5,06 ini menunjukan ROE masih dikatakan baik walau terjadi penurunan dari tahun 2017 sebesar 0,95\% kemudian pada tahun 2019 rata-rata suku bunga 
bank sebesar 5,63 ini menunjukan ROE lebih kecil dibandingkan dengan suku bunga yang berarti kondisi perusahaan pada tahun 2019 sedang tidak baik dan terjadi penurunan drastis dari tahun 2018 sebesar 8,17\% menjadi 4,12\% atau penurunan sebesar 4,05\%. Setelah mengetahui probability ROE di PT. Angkasa Pura pada tahun 2017-2019 ternyata mengalami penurunan dan pada tahun 2019 dapat dikatakan bahwa kondisi perusahaan sedang tidak dalam kondisi sehat.

Jika dilihat pada tabel EPS pun mengalami penurunan yang artinya manajemen tidak mampu meningkatkan kesejahteraan pemegang saham bahkan sangat terlihat pada tahun 2018 ke 2019 yang mengalami penurunan drastis sebesar 22\%. Ini disebabkan oleh laba yang diperoleh dalam 3 tahun (2017-2019) terus berkurang. Dan peningkatan jumlah saham yang beredar namun tidak diimbangi dengan laba yang diperoleh. Dari semua data untuk melihat apakah perusahaan dalam keaddan baik atau tidak bisa dikatakan bahwa pada tahun 2019 perusahaan dalam kondisi tidak baik terbukti dari perhitungan mencari probabilitas menggunakan ROE dan EPS yang menunjukan adanya penurunan drastis yang terjadi di tahun 2019 walau sebenarnya perusahaan masih mendapatkan laba namun tidak sebaik di 2 tahun sebelumnya.

\section{E. KESIMPULAN}

1. Likuiditas PT Angkasa Pura II menunjukkan bahwa perusahaan mampu atau likuid dalam memenuhi kewajibannya karena memiliki hasil rasio diatas rata-rata terutama pada Qurrent Ratio dan Cash Ratio, meski dari tahun ke tahun menurun namun perusahaan ini masih likuid. Dengan hutang lancar yang selalu meningkat dan aktiva lancar yang menurun, PT Angkasa Pura II memiliki ancaman dalam memenuhi kewajibannya, ancaman terbesarnya adalah perusahaan pailit.

2. Dilihat dari rasio solvabilitas yang terdiri dari DAR, DER, LTDTER dan TIE, Selama 3 tahun terakhir rasio DAR (Debt to asset ratio) menunjukkan peningkatan yang artinya semakin banyak pendanaan berasal dari utang. Terdapat kekhawatiran perusahaan akan sulit mendapatkan tambahan pinjaman karena akan semakin sulit menutupi utangnya dengan aktiva yang dimilikinya. Rasio DER (Debt to equity 
ratio) selama 3 tahun terakhir menunjukkan peningkatan ini menunjukkan komposisi total hutang semakin besar dibanding dengan total modal sendiri, sehingga berdampak semakin besar beban perusahaan terhadap pihak luar (kreditur).. Long Term Debt to Equity Ratio (LTDTER) perusahaan mengalami kenaikan setiap tahunnya. Kenaikan tersebut disebabkan karena ekuitas perusahaan mengalami kenaikan setiap tahunnya walaupun utang jangka panjang nya mengalami kenaikan juga,tetapi tota ekuitas masih jauh lebih tinggi jika dibandingkan dengan utang jangka panjangnya. Oleh karena itu perusahaan dapat dikatakan baik, karena perusahaan lebih banyak menggunakan modal sendiri daripada menggunakan utang jangka panjang.Dan Time Interest Earned Ratio (TIE) perusahan mengalami penurunan setiap tahunnya. Penurunan tersebut disebabkan karena setiap tahun beban bunga perusahaan mengalami kenaikan sedangkan pendapatan atau laba perusahaan mengalami penurunan, walaupun laba perusahaan mengalami penurunan tetapi total laba perusahaan masih lebih tinggi jika dibandingkan dengan beban bunga perusahaan. Dan walaupun mengalami penurunan, tetapi perusahaan masih mampu menutupi atau membayar beban bunganya, jadi perusahaan masih dapat dikatakan aman karena rasio nya pun masih diatas 1,5 .

3. Dari analisis rasio aktivitas, kinerja PT. Angkasa Pura II masih kurang baik jika dilihat pada rasio Total Asset Turnover, Working Capital Turnover dan Fixed Asset Turnover karena masih terdapat penurunan pada beberapa periode. Dan diharapkan manajemen dapat memanfaatkan setiap rupiah aktiva untuk menghasilkan penjualan dan mengefektifkan penggunaan aktiva tetap.

4. Dari analisis profitabilitas pada rasio ROE (Return On Equity) ternyata laba yang dihasilkan semakin tahun semakin turun sehingga dapat dikatakan bahwa kondisi perusahaan sedang tidak dalam kondisi sehat pada periode 2019 karena ROE tahun itu lebih kecil dibandingkan denga bunga Bank. begitu pula perhitangan EPS (Laba per lembar saham) yang menunjukan penurunan yang signifikan di tahun 2018 ke 2019 sebesar 
22\%. Dan untuk memperbaiki di tahun selanjutnya harus mengetahui kekuatan, kelemahan, peluang, serta ancaman sehingga laba yang diperoleh dapat meningkat.

PT. Angkasa Pura II (Persero) diharapkan dapat lebih meningkatkan kinerjanya terutama kinerja keuangan sehingga dapat menjaga kestabilan perusahaan dan dapat menjaga kesehatan perusahaan. Dan diharapkan perusahaan juga dapat mempertahankan bahkan meningkatkan kembali kekuatan yang dimiliki perusahaan sehingga dapat menciptakan peluang dan dapat mencegah ancaman serta melindungi kelemahan yang dimiliki perusahaan.

\section{DAFTAR PUSTAKA}

Afriyani, E. (2008). Penilaian Kinerja Keuangan Dengan Menggunakan Analisi Rasio.03 (02). Jurnal Ekonomi Bismis

Ikatan Akuntansi Indonesia (IAI). 2009. Standar Akuntansi Keuangan (SAK) Tahun 2009. Jakarta : Salemba Empat

Ikatan Akuntansi Indonesia (IAI). 2009. Standar Akuntansi Keuangan. Jakarta : Salemba Empat

Kasmir. 2015. Analisis Laporan Keuangan. Jakarta : Raja Grafindo Persada

Michael, Nengah, Sri. 2017. Penggunaan Rasio Keuangan Untuk Mengukur Kinerja Keuangan Perusahaan (Studi pada PT. Otoparts Tbk dan PT. Goodyear Indonesia Tbk). Jurnal. Fakultas Ilmu Administrasi. Universitas Brawijaya Malang.

Mulyadi. 2001. Akuntansi Manajemen : Konsep, Manfaat dan Rekayasa. Edisi Ketiga. Jakarta : Salemba Empat

Munawir. 2001. Akuntansi Keuangan dan Manajemen. Edisi pertama. Yogyakarta : BPEE

Munawir. 2007. Analisis Laporan Keuangan. Edisi Empat. Cetakan keempat belas. Yogyakarta : Liberty

Munawir. 2010. Analisis Laporan Keuangan, Konsep dan Aplikasi. Yogyakarta : Liberty

Sugiyono. 2008. Metode Penelitian Kuantitatif Kualitatif dan R\&D. Bandung : Alfabeta

Website : www.angkasapura2.co.id 